\title{
Excange Rate Fluctuation and Real Sector Performance in Nigeria: A Disaggregated Analysis
}

\author{
Olajide Emmanuel Falana, PhD
}

Department of Banking and Finance, Adekunle Ajasin University, Akungba Akoko, Akungba- Akoko, Ondo State, Nigeria

Doi:10.19044/esj.2019.v15n25p358 URL:http://dx.doi.org/10.19044/esj.2019.v15n25p358

\begin{abstract}
The Nigerian real sector is facing serious challenges due to exchange rate volatility. All the past efforts of the Central Bank of Nigeria to make naira have high international competitiveness had not yielded much result. In view of this, this study investigates the relationship between exchange rate fluctuation and the performance of the real sector in Nigeria while looking at disaggregated components of agricultural, industrial, building and construction, wholesale and retail trade, and services with a scope spanning thirty-two years, covering the period from the commencement of SAP in 1986 up to 2017. The study adopts the modified Mundell-Fleming IS-LM framework using Autoregressive Distributed Lag (ARDL) technique. The bounds tests suggest that the variables of interest are bound together in the long run with the aggregate real output (the dependent variable). This same pattern exists between the sectoral outputs and their independent variables, with the exception of Agriculture Output. The study also reveals a long-term inverse and significant relationship between exchange rate and both aggregate output and the outputs of each of the five sectors of the Nigeria real economy. The study further establishes that the sectors of the economy responded heterogeneously to exchange rate change. However, the pattern of each sector's response to exchange rate change is far from pure homogeneity, affirming the disparity in terms of size, magnitude. The major implication of the findings is that exchange rate strategies adopted by government could not spur the desired improvement in the performance of real sector in Nigeria. The study, therefore, recommends that the monetary authorities should re-assess, monitor, and enforce the existing exchange rate policies in Nigeria with a view to stimulating increased performance of the real sector of the economy. The government should also develop an extensive programme of development of domestic industries to stimulate exports, cut non-productive imports, and create employment. There is also the need to put in place and implement
\end{abstract}


coordinated macroeconomic policies that would attract foreign private investment, reduce poverty level, and stimulate exchange rate stability.

Keywords: Exchange rate fluctuation, real sector, Nigerian economy

\section{Introduction}

The large and developing economy of Nigeria is vastly endowed with abundant natural and human resources with highly diversified ecological conditions (National Bureau of Statistics, 2014). The International Monetary Fund (IMF) placed Nigeria's economy as the biggest in Africa with a GDP of $\$ 493.83$ billion in 2015, ahead of South Africa and Egypt coming second and third respectively (International Monetary Fund, 2016).

The huge decline in the growth of Nigeria economy, coupled with other economic plights, including huge decline in the country's oil output, infrastructural decay, and persistent inflation is blamed mainly on the depreciation of the naira over the years (World Bank, 2017).

The real sector is fundamentally crucial to the growth of any nation and is the pillar upon which the government's objectives of inclusive growth and poverty reduction hinge. The productive capability of a real sector actually depends on its vibrancy.

A vibrant real economy creates more activity channels in the economy and promotes internal and external balance (Anyanwu, 2010; Ibadin, Moni \& Eikhomun, 2014). It is worrisome that the Nigerian real sector has not attained the desired development despite her enormous resource endowment; this is due largely to lack of suitable exchange rate management (Odusola, 2006). Thus, exchange rate becomes an integral part of a nation's macroeconomic policy, having great impact on the real sector. An effective exchange rate policy is considered an essential condition for boosting economic performance (Obadan, 2006; Chang \& Tan, 2008).

\subsection{Statement of Problem and Objectives of the Study}

Ongoing discussions surrounding the appropriate exchange rate policy have lingered in developing countries. Chief among the subjects of these persistent deliberations has been the degree of fluctuation in the exchange rate in the face of internal and external shocks and their effects on real output growth (Kandil, 2004). Exchange rate has a significant influence on the performance of not only real economy but also the behaviour of some other macroeconomic variables, especially in a country like Nigeria which had pursued the objective of sustainable growth while coping with high import dependency (Oyejide, 1985; Aliyu, 2008; Adeniyi, 2012).

Evidently, the achievement of a suitable exchange rate policy has become a major challenge facing Nigerian monetary authority (Central Bank of Nigeria) 
over a few years and the failure to achieve a stable exchange rate has hampered the performance of the real sector and its component units (Fapetu \& Oloyede, 2014). According to Ayodele (2004), the Nigerian real sector is underperforming due to several problems ranging from exchange rate volatility, feeble industrial base, low productivity in agriculture, import dependence, high external debt overhang, as well as inefficient public utilities. So far, the successive exchange rate policies in Nigeria have not guided the Nigerian real sector to the desired position (International Monetary Fund, 2017). It is quite startling that the Nigerian economy continues to depend on a single commodity for the greater proportion of its foreign exchange earnings while the output of agriculture, which used to be the mainstay of the economy prior to the discovery of oil, continues to dwindle (Yaqub, 2010).

Further, the continuing disappearance of the traditional exports and absolute reliance on oil for foreign exchange earnings expose the country to the uncertainties of world oil market which have become progressively unpredictable (Olorunfemi \& Fatukasi, 2011).

Despite the situations discussed above, existing studies on the relationship between exchange rate and real output performance in developing countries, and particularly Nigeria, had largely focused on aggregate output and a single sector component of real economy. However, in reality, the impact of exchange rate could differ substantially across sectors because of differences in sector structures and compositions. Empirical evidences on the sectoral responses to exchange rate changes are scanty. Departures from the extant literature were Yaqub (2010) and Olajide (2016). Although the extant studies considered the sectoral perspective of this subject, they focused on just three sectors: Agriculture, Manufacturing, and Service. Against this backdrop and given the significance of a disaggregated study and the dearth of studies in this area which is a major omission in the literature, the broad objective of this research is to examine the effects of exchange rate fluctuation on the performance of sectoral output of the five sectors of the Nigerian real economy, namely: agriculture, industry, building and construction, wholesale/retail trade, and services using the Central Bank of Nigeria's (CBN's) real output classification in line with the production boundary of the System of National Accounts (SNA).

The specific objectives of the study include to:

i. examine the effect of exchange rate fluctuation on the performance of aggregate real output in Nigeria;

ii. evaluate the difference in the response of the five components of the Nigeria Real sector to fluctuation in exchange rate;

The following hypotheses which are all in null form were formulated and tested in the study: 
i. The exchange rate has no significant effect on Aggregate Real Output Performance in Nigeria

ii. There is no significant difference in the response of each of the five components of real output to exchange rate fluctuation in Nigeria.

\subsection{Significance of the Study}

The significance of this study is predicated on the prominence of recent developments in international finance which had progressively brought the issue of relationship between exchange rate and real sector performance into special focus with increased and continued attractions of the theoretical and empirical researches. A major significance of this study lies in the fact that there is a dearth of empirical information in Nigeria on the relationship between exchange rate and the performance of the outputs of the disaggregated real sector; particularly, at a time when the country's monetary authority is battling with unabated depreciation of the Naira. The study may thus be a current exposition of the subject with a scope spanning thirty-two years (i.e., 1986 to 2017) which adequately covered the period from the commencement of SAP in 1986 up to 2017. The study would serve as a very relevant guide for policy makers in Nigeria and other developing countries.

\subsection{Review of Extant Literature on Exchange Rate Fluctuations and Real Sector Performance}

The nexus between exchange rate and real sector performance has attracted huge attention in the literature for both developing and developed economies. The topic continues to enjoy growing degree of studies. However, the debate on the effect of exchange rate changes on the performance of the real economy is far from been resolved on both theoretical and empirical surfaces of literature. In addition, majority of theoretical and empirical investigations in Nigeria have dealt primarily with aggregate variables and paid little attention to sectoral dimension. This is far from reality, given the obvious interdependence among the subsectors of the real economy and the implications of this for theoretical models as well as the general functioning of a nation's real economy.

\subsection{Conceptual Literature}

Exchange rate is the value of a country's currency in relation to another nation's currency. Looking at the context of the Nigerian naira and the United States of American dollar, the exchange rate of naira is the quantities of naira required to purchase one unit of the United States' dollar (Oloyede, 2002; Campbell, 2010; Ngerebo-a \& Ibe, 2013). Exchange rate can also be interpreted as the strength of a domestic currency when measured against another country's (trading partner) currency (Jhingan, 2003). The exchange 
rate is a vital price that determines the level of internal and external stability in any economy (Oladipupo \& Ogheneov, 2011). Exchange rate policy covers the designs, programmes, strategies, and systems to ensure a stable and effective exchange rate for the country's domestic currency, in consonance with overall macroeconomic policy objectives (Mordi, 2006).

The real sector is described as the sector of the economy where raw materials and other production factors such as labour, land, and capital are utilized for production. The sector therefore forms the main hub of any economy, as well as the agent of economic growth and development (Adeusi \&Aluko, 2015). The real sector comprises agriculture, industry, building and construction, and services (Sanusi, 2011). Recent studies have expanded the scope of the Nigeria real sector to include Agriculture, Industry, Building and Construction, Wholesale and Retail, and Services in consistence with the Central Bank of Nigeria (CBN) reporting format (Mordi et al., 2013 \& Amoo et al., 2014). Among these sectors, the activities in the Industrial and agricultural sectors are more prominent and dominant in Nigeria because changes in these subsectors will have considerable effects on the other subsectors and economic fundamentals such as employment, inflation, and economic growth (Akinlo \& Lawal, 2015).

\subsection{Theoretical Literature}

Fluctuation in the exchange rate follows a trend that is consistent with variation in macroeconomic fundamentals over time. Aggregate demand is affected by currency depreciation through exports and imports and aggregate supply is affected through the cost of imported intermediate goods. With respect to demand side, a positive change in exchange rate of the domestic currency (currency appreciation) will make exports more expensive than imports resulting in increased competition from foreign markets and demand for imports which will lead to a fall in the demand for domestic products. On the supply side, a positive variation in the exchange rate (an appreciation) leads to a decrease in the cost of imported intermediate goods while the cost of domestic output increases. The resultant effect is an increase in demand for imports. Moreover, the elasticity of product substitution determines the combined effects of currency fluctuations on consumption and investment. The higher the substitution, the more the reduction in imports will be offset by increase in private consumption and investment. The trade balance may also improve or deteriorate with respect to currency fluctuations.

This study is constructed on the Mundell-Fleming IS/LM model - an economic model by Mundell (1963) and Fleming (1962) which is an extension of the traditional IS-LM Model. The model portrays an open economy and a short run relationship between an economy's nominal exchange rate, interest rate, and output with the underlying assumption that output is demand- 
determined. The demand side of the economy consists of three markets: the goods, money, and the foreign exchange market, all of which must simultaneously be in equilibrium for the economy to be in stability. The Mundell-Fleming model provides understanding of how exchange rate is determined and also assumes a trilemma that perfect capital mobility, monetary policy independence, and a fixed exchange regime cannot be achieved simultaneously.

The Mundell-Fleming model is based on the following equations:

The IS curve:

$\mathbf{Y}=\mathbf{C}+\mathbf{I}+\mathbf{G}+\mathbf{N X}$

Where $Y$ is GDP, $C$ is consumption, $I$ is investment, $G$ is government spending and $N X$ is net exports.

The LM curve:

$\frac{\mathrm{M}}{\mathrm{P}}=\mathrm{L}(\mathrm{i}, \mathrm{Y})$

Where $M$ is money supply, $P$ is price level, $L$ is liquidity, $Y$ is GDP and $i$ is the interest rate

A higher interest rate or a lower GDP level leads to lower money demand.

IS components

$\mathrm{C}=\mathrm{C}[\mathrm{Y}-\mathrm{t}(\mathrm{Y}), \mathrm{I}-\mathrm{E}(\mathfrak{£})]$

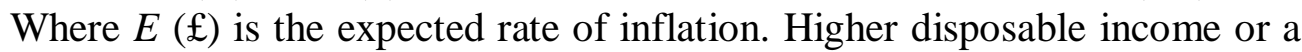
lower real interest rate (nominal interest rate minus expected inflation) leads to higher consumption spending.

$\mathrm{I}=\mathbf{I}\left(\mathbf{I}-\boldsymbol{E}(£), \boldsymbol{Y}_{\mathbf{- 1}}\right.$

where $Y_{-1}$ is GDP in the previous period. Higher lagged income or a lower real interest rate leads to higher investment spending.

$N X=N X(e, Y, Y *)$

Where $N X$ is net exports, $e$ is the nominal exchange rate, $Y$ is GDP, and $Y^{*}$ is the combined GDP of foreign trading partners. Higher GDP leads to more expenditure on imports and, hence, lower net exports; higher foreign income leads to higher expenditure by foreigners on the country's exports and, thus, higher net exports. A higher $e$ leads to lower net exports $N X$.

\subsection{Related Empirical Literature}

The empirical literature on the relationship between exchange rate and real output performance is extensive. Early studies in the developed world and on few developing countries such as Diaz-Alejandro (1965); Bernanke and Gertler (1995); Raddatz and Rigobon (2003); Kowalski, Paczynski and Rawdanowicz (2003); Levy-Yeyati and Sturzenegger (2003); Llaudes (2007); Kamin and Klau (1998); Moreno (2001); Kandil (2004) have yielded ambiguous results. 
Empirically, in the case of Nigeria, quite a number of studies have investigated the effect of exchange rate on the real sector at a very high degree of aggregation or at the individual components of the real sector studied in isolation. Akpan and Atan (2012) investigated the effect of exchange rate movements on real output growth in Nigeria based on quarterly series for the period 1986 to 2010. The study specifically examined the possible direct and indirect relationships between exchange rates and GDP growth using Generalised Method of Moments (GMM) and found evidence of a strong direct relationship between changes in exchange rate and output growth. Obayelu and Salau (2010) also evaluated agricultural output response to changes in prices and exchange rate in Nigeria using the Co-integration and Vector Error Correction (VEC) techniques. The results showed that food and export prices as well as the real exchange rate jointly explained 57 percent of the variation in agricultural output in the short run and 87 percent variation in the long run. Results further revealed that food crop prices and exchange rate are passed on immediately to agricultural output. The study recommended the need to strengthen the link between agriculture and the manufacturing sector through local sourcing of raw materials, and thereby reducing the reliance of the sector on import of inputs to a reasonable level. Musa and Sanusi (2013) investigated the response of aggregate industrial output to relative change in prices and exchange rate in Nigeria between 1970- 2011, using a Vector Error Correction (VEC) model. The empirical findings indicated a significant relationship between exchange rate and industrial output in Nigeria. Akinlo and Lawal (2015) examined the impact of exchange rate on industrial production in Nigeria over the period 1986-2010 using the Vector Error Correction Model (VECM) and showed that exchange rate depreciation had no observable impact on industrial production in the short run but had positive impact in the long run.

As mentioned earlier, the only known studies with sectoral perspective in Nigeria were carried out by Yaqub (2010) and Olajide (2016). Yaqub (2010) investigated the relationship between Exchange Rate Changes and Output Performance in Nigeria; looking at just three subsectors of Agriculture, Manufacturing, and Services. The study adopted the modified IS-LM framework and estimated the behavitheal equations as a system using the Seeming Unrelated Regression Estimation (SURE) technique to estimate data on Nigeria from 1970-2007. Olajide (2016) studied the Real Sector Performance and the Exchange Rate Dynamics using the Keynesian aggregate demand-aggregate supply framework as well as a dynamic recursive econometric specification with the aim of examining the response of the real sector and its components to exchange rate movements-between 2010 and 2013. The results revealed a trade-off between the performance of the agricultural and industrial sector due to exchange rate shocks and exchange 
rate policy while services output becomes volatile on account of exchange rate shocks and exchange rate management.

From the empirical literature, it is obvious that most of the formal empirical studies carried out on exchange rate-real output growth relationships and other related issues, particularly in Nigeria-focused more on the aggregate sector and therefore lacked sectoral insight and also missed informative advantage in disaggregated approach. This is a critical shortcoming in the literature. More so, the two extant studies restricted their scope to agriculture, manufacturing, and services sectors. But by far broader than the extant studies, this study covers the five major sectors of agriculture, industry, building and construction, trade, and services based on the Central Bank of Nigeria $(\mathrm{CBN})$ which disaggregated real output classification in line with the production boundary of the System of National Accounts (SNA).

\subsection{Theoretical Framework and Methodology}

This study is empirical and analytical in nature designed to quantitatively determine the relationship between exchange rate fluctuation and the performance of components of the real sector in Nigeria. Due to the nature of this study and the variables that are involved, ex-post facto design was adopted. Ex-post designs by nature rely heavily on secondary (already computed) data. The data for this study are mainly time series obtained from secondary sources, namely: the annual publications (various issues) of the National Bureau of Statistics (NBS), Central Bank of Nigeria Statistical Bulletin and Annual Reports/Statement of Accounts (various issues), and World Development Indicators of World Bank. Annual data for the period 1986-2017 are employed in the study.

\subsection{Model Formulation}

This study examines the relationship between exchange rate fluctuations and real output (real GDP), of the aggregate economy and the five components of the real economy. The theoretical construct of the model is rooted in the adapted IS-LM framework, which was also adopted by Kandil (2004) as well as Kandil and Mirzai (2002, 2005). In this framework, the output is assumed to be demand-determined and the economy attains both internal and external equilibrium, which is the objective of exchange rate management. The framework also describes an open economy with a short run relationship between an economy's nominal exchange rate, interest rate, and output. Drawing from the theoretical and empirical literature, the study exploits an empirical model that replicates the expanded form of the model. The model is stated below:

$P Y_{t}=\alpha_{0}+R(L) Y_{t-1}+Q \varepsilon_{t}$ 
The model is modified accordingly based on the peculiarity of this study, the structure of data used, as well as to accommodate some relevant variables to reflect the reality of the Nigerian economy. Net Export was added to the models as an open economy indicator. Other relevant variables (such as government capital expenditure, government recurrent expenditure, total government expenditure, rainfall, credit to the private sector, and index of electricity consumption) were added in disaggregated output equations which were presented accordingly in various models.

Two models were formulated based on the objectives of this study.

\section{Model 1: The Effect of Exchange rate Fluctuation on the Aggregate Real Output in Nigeria}

For Model 1, which considers whether exchange rate has significant effect on aggregate real output in Nigeria, the null hypothesis that 'exchange rate has no significant effect on Real Output Performance in Nigeria' is tested.

The model is specified in a functional form as stated below:

\section{RGDP $=\boldsymbol{f}$ (NER, INF, PLR, NE, GCE, CPS)}

The model can thus be written in econometrics form by specifying that: $R G D P_{t}=\beta_{0}+\beta_{1} N E R_{t}+\beta_{2} I N F_{t}+\beta_{3} P L R_{t}+\beta_{4} N E_{t}+\beta_{5} G C E_{t}+\beta_{6} C P S_{t}+\mu_{t}--$

From the functional equation, Real Output (RGDP) is a function of Nominal Exchange Rate (NER), Inflation (INF), Prime Lending Rate (PLR), Net Export (NE), Government Capital Expenditure (GCE), and Credit to Private Sector (CPS).

The equation is represented in structural form below:

$P Y_{t}=\alpha_{0}+R(L) Y_{t-1}+Q \varepsilon_{t}$

Where

$Y_{t}=$ vector of endogenous macroeconomic variables used in aggregate output (comprising aggregate real GDP, nominal exchange rate, inflation rate, Prime Lending Rate and Net Export, Government Capital Expenditures, as well as Credit to the Private Sector). The Net Export is introduced to capture the export-import channel in the model. The variables are first transformed into natural logs (except the ones in percentage form) before computations, with a view to removing possible heteroscedasticity.

$Y_{t-1}=\mathrm{a}$ vector of the lagged values of endogenous variables,

$\varepsilon_{t}=$ a vector of random error of disturbance terms for variable that contains exogenous factors.

$R(L)=$ a matrix polynomial in the lag operator $L$ of length $p$, $P=$ a matrix of $n^{\prime} n$ dimension, $n$ is the number of variables, and

$Q=$ a column vector of dimension $n \times 1$, which contains the contemporaneous response of the variables to the innovations. 
Model 2: Exchange Rate Fluctuation and the Five Different/Disaggregate Components of Real Output in Nigeria

The study models the output equations for Agricultural, Industry, Building and Construction, Wholesale and Retail trades, and Services sectors to reflect the peculiar characteristics of each sector. The equation is represented as follows: $A Y_{t}=\beta_{\mathrm{o}}+C(L) Y_{t-1}+B \varepsilon_{t}$

Where

$Y_{t}=$ vector of endogenous macroeconomic variables used in each of the sectors, $Y_{t-1}=$ a vector of the lagged values of endogenous variables of each of the subsector,

$\varepsilon_{t}=\mathrm{a}$ vector of random error of disturbance terms for every variable that contains exogenous factors,

$C(L)=$ a matrix polynomial in the lag operator $L$ of length $p$,

$A=$ a matrix of $n$ ' $n$ dimension, $n$ is the number of variables, and

$B=$ a column vector of dimension $n \times 1$, which contains the contemporaneous response of the variables to the innovations.

Furthermore, because this study is interested in sectoral analysis, output equations are modeled for the agricultural, industrial, building and construction, trade, and services sectors. The equation for each sector is designed to reflect its peculiar characteristics. The functional forms of relationship among the variables in each sector are stated in turn:

\section{Agricultural Output}

Production in this sector is specified in the model as the function of nominal exchange rate (NER), Inflation (INF), Prime Lending Rate (PLR), Net Export (NE) rainfall $(R f)$, and Credit to Private Sector (CPS) (Yaqub, 2010; Mordi et al., 2013).

The equation for Agricultural output is specified in a functional form as:

Agric RGDP $=f(\mathrm{NER}, \mathrm{INF}, \mathrm{PLR}, \mathrm{NE}, \mathrm{Rf}, \mathrm{CPS})$

The function is written in time series econometrics form as:

$$
A G R I C R G D P_{t}=\delta_{0}+\delta_{1} N E R_{t}+\delta_{2} I N F_{t}+\delta_{3} P L R_{t}+\delta_{4} N E_{t}+\delta_{5} R F+\delta_{6} C P S+\mu_{2 t}-(3.5)
$$

\section{Industrial Output}

This sector is modeled in this study to include nominal exchange rate, Inflation rate, Prime Lending Rate, Net Export, index of electricity consumption, credit to private sector, and government capital expenditure (Mordi et al., 2013). Government Capital Expenditure, Credit to Private Sector, Net Export and Index of Electricity Consumption are expected to have a positive influence on output of industrial sector, while the nominal exchange rate, inflation rate, and prime lending rate should have negative impact on the sector.

The equation for Industrial output is specified in a functional form as: 
Ind RGDP $=f(\mathrm{NER}, \mathrm{INF}, \mathrm{PLR}, \mathrm{NE}, \mathrm{IEC}, \mathrm{GCE}, \mathrm{CPS})$

The function is written in time series econometrics form as:

$$
I N D R G D P_{t}=\gamma_{0}+\gamma_{1} N E R_{t}+\gamma_{2} I N F_{t}+\gamma_{3} P L R_{t}+\gamma_{4} N E_{t}+\gamma_{5} I E C_{t}+\gamma_{6} G C E+\gamma_{7} C P S_{t}+\mu_{3 t}
$$

\section{Building and Construction Output}

The output of building and construction (Build RGDP) is likely to be determined by government capital expenditure (GCE), nominal exchange rate (NER), inflation rate (INF), and Prime Lending Rate (PLR) which measures the cost of funds and Credit to Private Sector (CPS). Government Capital Expenditure and Credit to Private Sector are expected to have a positive influence on output of building and construction, while the nominal exchange rate, inflation rate, and prime lending rate should have negative impact on building and construction output.

The Building and Construction output is specified in a functional form as:

Build. RGDP $=f(\mathrm{NER}, \mathrm{INF}, \mathrm{PLR}, \mathrm{GCE}, \mathrm{CPS})$

The function is written in time series econometrics form as:

$$
B U I L D R G D P_{t}=\lambda_{0}+\lambda_{1} N E R_{t}+\lambda_{2} I N F_{t}+\lambda_{3} P L R_{t}+\lambda_{4} G C E_{t}+\lambda_{5} C P S_{t}+\mu_{4 t}----
$$

\section{Wholesale and Retail Trade Output}

The output of Trade (Trade RGDP) is specified to be determined by nominal exchange rate (NER), inflation rate (INF), Prime Lending Rate (PLR), Net Export (NE), Government Capital Expenditure (GRE), and Credit to Private sector (CPS). Government Capital expenditure, Credit to Private Sector, and Net Export are expected to exert positive influence on wholesale and retail trade output, while nominal exchange rate, inflation rate, and prime lending rate are expected to have negative influence on it.

The equation for Wholesale and Retail Trade output is specified in a functional form as:

Trade RGDP $=f(\mathrm{NER}, \mathrm{INF}, \mathrm{PLR}, \mathrm{NE}, \mathrm{GCE}, \mathrm{CPS})$.

The function is written in time series econometrics form as:

$T R A D E R G D P_{t}=\phi_{0}+\phi_{1} N E R_{t}+\phi_{2} I N F_{t}+\phi_{3} P L R_{t}+\phi_{4} N E_{t}+\phi_{5} G C E_{t}+\phi_{6} C P S_{t}+\mu_{5 t}(3.8)$

\section{Services Output}

Output of services sector is determined by nominal exchange rate (NER), inflation rate (INF), Prime Lending Rate (PLR), Net Export on Services, and total government expenditure (TGE).

The equation for Services output is specified in a functional form as:

Service RGDP $=f(\mathrm{NER}, \mathrm{INF}, \mathrm{NES}, \mathrm{PLR}, \mathrm{TGE}, \mathrm{CPS})$

The function is written in time series econometrics form as:

SERVICERGDP $P_{t}=\xi_{0}+\xi_{1} N E R_{t}+\xi_{2} I N F_{t}+\xi_{3} N E S_{t}+\xi_{4} P L R_{t}+\xi_{5} T G E+\xi_{6} C P S+\mu_{6 t}--(3.9)$ 
A priori Expectation: All the variables except total government expenditure (TGE), Net Export on Services and Credit to the Private Sector are expected to have negative effect on output of Services subsector.

\subsection{Descriptions and Measurement of Variables}

Below are short descriptions of various variables adopted as proxies in the specification.

Table 3.1. Descriptions and Measurement of Variables

\begin{tabular}{|c|c|c|c|}
\hline SN & VARIABLE & SYMBOL & MEASUREMENT \\
\hline 1 & Aggregate Output & RGDP & Aggregate RGDP measured in naira \\
\hline 2 & Agricultural Output & Agric RGDP & Agric component of RGDP in naira \\
\hline 3 & Industry Output & Ind RGDP & Industry component of RGDP in naira \\
\hline 4 & Building \& Const. Output & Build RGDP & $\begin{array}{l}\text { Building \& Construction component of } \\
\text { RGDP in naira }\end{array}$ \\
\hline 5 & Trade(Commerce) Output & Trade RGDP & Trade component of RGDP in naira \\
\hline 6 & Service Output & Service RGDP & Agric component of RGDP in naira \\
\hline 7 & Nominal Exchange Rate & NER & $\begin{array}{l}\text { Units of the Naira that can purchase a unit } \\
\text { dollar }\end{array}$ \\
\hline 8 & NominalEffectiveExchange Rate & NEER & $\begin{array}{l}\text { value of the Naira in terms of those of Nigeria } \\
\text { major trading partners }\end{array}$ \\
\hline 9 & Inflation rate & INF & $\begin{array}{l}\text { Inflation/Consumer Price Index (CPI) is the } \\
\text { average change over time in prices of goods } \\
\text { and services consumed by people }\end{array}$ \\
\hline 10 & Prime Lending Rate & PLR & $\begin{array}{l}\text { Lending rate to less prime/less risky real } \\
\text { sector }\end{array}$ \\
\hline 11 & Maximum Lending Rate & MLR & Average highest rate to risky real sector \\
\hline 12 & Net Export & $\mathrm{NE}$ & $\begin{array}{l}\text { Export minus Import (in Naira). Represent } \\
\text { openness }\end{array}$ \\
\hline 13 & Net Export of Goods & NEG & $\begin{array}{l}\text { Export of goods minus Import of goods (in } \\
\text { Naira) }\end{array}$ \\
\hline 14 & Net Export of Services & NES & $\begin{array}{l}\text { Export value of services minus Import value } \\
\text { of services }\end{array}$ \\
\hline 15 & Credit to Private Sector & CPS & $\begin{array}{l}\text { Total financial resources provided by } \\
\text { financial institution in Naira }\end{array}$ \\
\hline 16 & Government Capital Expenditure & GCE & $\begin{array}{l}\text { Spending on acquisition of goods and } \\
\text { services for future benefit (in Naira) }\end{array}$ \\
\hline 17 & Government Recurrent Expenditure & GRE & $\begin{array}{l}\text { Value of spending on other purposes other } \\
\text { than capital cost in }\end{array}$ \\
\hline 18 & Total Government Expenditure & TGE & $\begin{array}{l}\text { Total Expenditure which is the addition of } \\
\text { GCE and GRE }\end{array}$ \\
\hline 19 & Rainfall & $\mathrm{Rf}$ & Quantity of rainfall in millimetres (mm) \\
\hline 20 & $\begin{array}{l}\text { Index of Electricity Consumption } \\
\text { (Energy) }\end{array}$ & IEC & $\begin{array}{l}\text { Total electricity energy, usually measured in } \\
\text { watts or kilowatts }\end{array}$ \\
\hline
\end{tabular}

Source: Author's Compilation (2019)

\subsection{Method of Estimation and Diagnostic Techniques}

Autoregressive Distributed Lag (ARDL) Technique is used for this study, due to consideration of its cointegration analysis which is unbiased and efficient. This technique has a number of advantages. First, it is useful in estimating the short and long run components of a model simultaneously, 
removing problems associated with omitted variables and autocorrelation (Narayan, 2004). Second, the ARDL cointegration approach could be used regardless of whether the underlying variables are $I(0), I(1)$, or fractionally integrated. This implies that the ARDL approach avoids the pre-testing problem associated with standard cointegration, which requires that the variables be already classified into I(I) (Pesaran, Shin \& Smith, 2001). Thirdly, the ARDL approach to cointegration is preferable to the Johansen approach because it avoids the problem of too many choices that are to be made in the Johansen method.

According to Pesaran and Pesaran (1997), the augmented ARDL $\left(p, q_{1}, q_{2} \ldots, q_{k}\right)$ can be written as follows:

n

$$
\alpha(L, p) y_{t}=\alpha_{o}+\Sigma \beta_{i}\left(L, q_{i}\right) x_{i, t}+\varepsilon t
$$

$i=1$

Where $\alpha_{o}$ is a constant, $y_{t}$ denotes the dependent variable, $L$ is a lag operator, $x_{i, t}$ is the vector of regressors (where $i=1,2, \ldots, n$ ) and $\varepsilon_{t}$ is the disturbance term.

The function in the long run is given as follows:

$$
\boldsymbol{y}_{\boldsymbol{t}}=\boldsymbol{y}_{t-1}=\ldots=\boldsymbol{y}_{t-q} \text { and } \boldsymbol{x}_{\boldsymbol{i}, \boldsymbol{t}}=\boldsymbol{x}_{\boldsymbol{i}, \boldsymbol{t}-1}=
$$

Where $x_{i, t-q}$ denotes $q^{\text {th }}$ lag of the $i^{\text {th }}$ variable.

The long run equation can be written as follows:

$\mathbf{n}$

$$
y_{t}=\alpha+\Sigma \beta_{i} x_{i}+\varepsilon_{t}
$$

It is a standard practice in empirical literature involving both time series and panel data to test for unit roots because economic and financial time series like exchange rates and macroeconomic aggregates like real GDP display non-stationarity in their mean. Estimating models that contain nonstationary variables will often lead to a grave consequence of spurious results, hence, making pre-testing for unit roots and cointegration a necessary first step in a typical time series modelling. Accordingly, unit root tests, such as Augmented Dickey-Fuller (ADF, 1981) and Phillips-Perron (1988) and Johanssen cointegration tests are used to determine the order of integration for each series. The study also uses Summary Statistics of the Series in order to determine their inter-relationships.

\subsection{Post Estimation/Diagnostic Tests}

Diagnostic tests for serial correlation, normality, stability, and heteroskedasticity for the estimated model are carried out. The models are subjected to heteroskedasticity tests using the Breusch-Pagan-Godfrey (BPG) tests. The B-G Serial Correlation LM test is used to test for higher order Autoregressive Moving Average errors in the model while the Ramsey 
(Regression Specification Error Test) RESET is used to examine the stability of the ARDL model.

\subsection{Empirical Analysis and Presentation of Results}

4.1. Descriptive Statistics

This section begins by conducting a descriptive statistics of the variables employed to understand their statistical properties. To this effect, Table 4.1 relates the descriptive statistics of the variables employed. The variables examined are real GDP (RGDP), Industrial Sectoral contribution to GDP (INDRGDP), Building and Construction Sectoral GDP (BUILDRGDP), Trade Sectoral GDP (TRADERGDP), Services Sectoral contribution to GDP (SERVICERGDP), Agricultural Sectoral contribution to GDP (AGRICRGDP), Government Capital Expenditure (GCE), Credit to Private Sector (CPS), Exchange Rate (NER), Inflation rate (INF), Prime Lending Rate (PLR), Net Export (NE), Rainfall (RF), Index of Electricity Consumption (IEC), Net Export on Services (NES) and Total Government Expenditure (TGE). The data are available from 1986 till 2017 except for Rainfall, index of electricity consumption, net export, and net export on services. 
Table 4.1. Descriptive Statistics

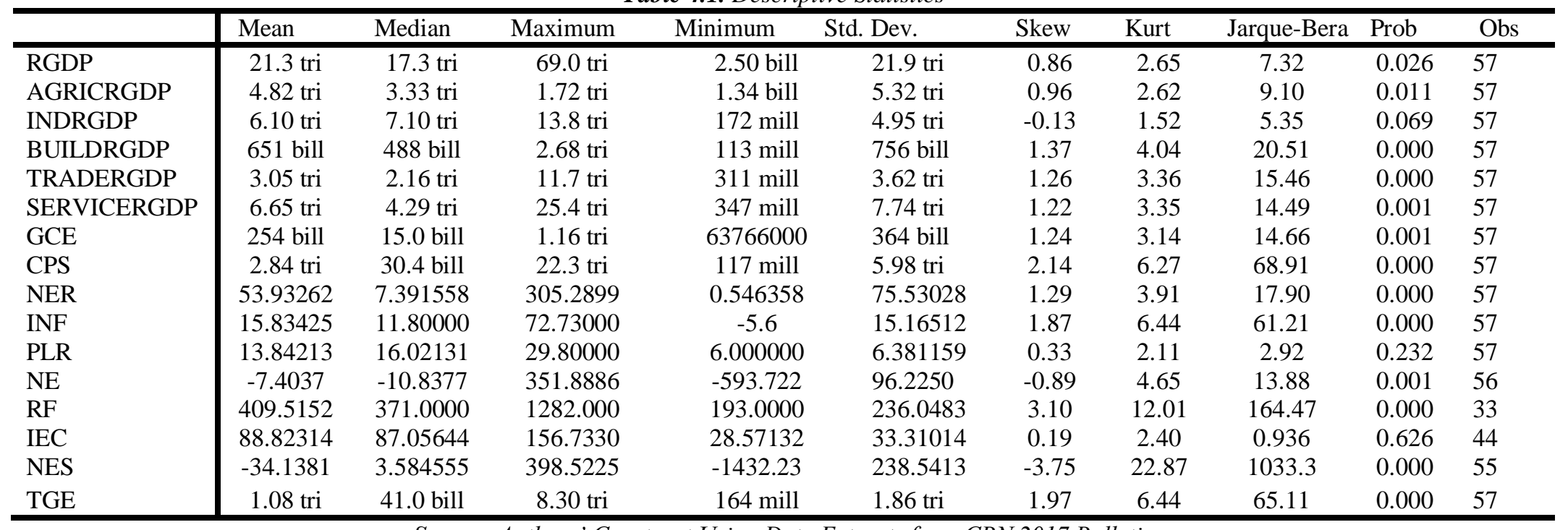

Source: Authors' Construct Using Data Extracts from CBN 2017 Bulletin 
From Table 4.1, real GDP grew from 2.5 billion naira to 69 trillion naira over the period under study; this shows that the economy has made tremendous impact in terms of their productive capacity over the period of study; this was also evidenced by the huge standard deviation of 21.9 trillion naira. Agricultural output also experienced a huge increase over the period of study; although it declined in growth pattern over the late 1980s due to the much concentration on oil resource as a major source of foreign exchange earnings; however, it has been able to muster an increase from 1.3 billion naira to 1.72 trillion naira. Services contribution to GDP on average maintained the highest over other sectors as it mustered an average of 6.65 trillion naira over the industrial sector contribution to GDP of 6.10 trillion and then agricultural sector contribution to GDP of 4.82 trillion naira. The five sectors have tremendously increased over the period of study from billions to trillions of naira. Exchange rate dwindled from a minimum of 0.55 to a dollar to 305.29 naira to a dollar over the period of study. Inflation rate also experienced a fluctuation from (5.6\%) to a maximum of $72.73 \%$ over the period of study. Total government expenditure also experienced a massive increase from 164 million naira experienced in 1961 to 8.30 trillion naira experienced in 2017. The Jarque-Berra test for normality shows that the variables of real GDP, Building and Construction Sector contribution to GDP, Trade Sector contribution to GDP, Services Sector contribution to GDP, Agricultural Sector contribution to GDP, Government Capital Expenditure, Credit to Private Sector, Exchange Rate, Inflation rate, Prime Lending Rate, Net Export, Rainfall, Net Export on Services, and Total Government Expenditure are rejected implying that they are not normally distributed while the variables of Industrial Sector contribution to GDP, Index of Electricity Consumption, and prime lending rate null hypothesis of normal distribution are rejected; the implication of this is that they are not normally distribute. 
Table 4.2. Correlation Result

\begin{tabular}{|c|c|c|c|c|c|c|c|c|c|c|c|c|c|c|c|}
\hline & RGDP & $\begin{array}{c}\text { IND } \\
\text { RGDP }\end{array}$ & $\begin{array}{l}\text { BUILD } \\
\text { RGDP }\end{array}$ & $\begin{array}{l}\text { TRADE } \\
\text { RGDP }\end{array}$ & $\begin{array}{l}\text { SERVIC } \\
\text { E RGDP }\end{array}$ & GCE & CPS & NER & INF & PLR & $\mathrm{NE}$ & $\mathrm{RF}$ & IEC & NES & TGE \\
\hline RGDP & 1.00 & & & & & & & & & & & & & & \\
\hline INDR GDP & 0.99 & 1.00 & & & & & & & & & & & & & \\
\hline BUILD RGDP & 0.92 & 0.92 & 1.00 & & & & & & & & & & & & \\
\hline TRADE RGDP & 0.99 & 0.99 & 0.92 & 1.00 & & & & & & & & & & & \\
\hline SERVICE RGDP & 0.99 & 0.97 & 0.92 & 0.98 & 1.00 & & & & & & & & & & \\
\hline GCE & 0.63 & 0.56 & 0.56 & 0.59 & 0.70 & 1.00 & & & & & & & & & \\
\hline CPS & 0.65 & 0.55 & 0.58 & 0.59 & 0.72 & 0.88 & 1.00 & & & & & & & & \\
\hline NER & 0.62 & 0.52 & 0.55 & 0.56 & 0.69 & 0.86 & 0.95 & 1.00 & & & & & & & \\
\hline INF & 0.22 & 0.25 & 0.18 & 0.27 & 0.20 & -0.12 & -0.08 & -0.08 & 1.00 & & & & & & \\
\hline PLR & 0.81 & 0.81 & 0.63 & 0.81 & 0.79 & 0.45 & 0.47 & 0.49 & 0.37 & 1.00 & & & & & \\
\hline $\mathrm{NE}$ & 0.07 & 0.11 & -0.02 & 0.08 & 0.05 & -0.23 & -0.10 & -0.13 & 0.15 & 0.18 & 1.00 & & & & \\
\hline RF & 0.29 & 0.20 & 0.24 & 0.22 & 0.35 & 0.48 & 0.72 & 0.69 & -0.17 & 0.23 & -0.13 & 1.00 & & & \\
\hline IEC & 0.80 & 0.81 & 0.66 & 0.82 & 0.78 & 0.29 & 0.36 & 0.33 & 0.35 & 0.76 & 0.08 & 0.14 & 1.00 & & \\
\hline NES & 0.29 & 0.30 & 0.25 & 0.30 & 0.29 & 0.16 & 0.14 & 0.12 & 0.05 & 0.30 & 0.17 & 0.12 & 0.05 & 1.00 & \\
\hline TGE & 0.65 & 0.56 & 0.58 & 0.59 & 0.72 & 0.96 & 0.97 & 0.96 & -0.10 & 0.48 & -0.18 & 0.63 & 0.33 & 0.14 & 1.00 \\
\hline
\end{tabular}

Source: Authors' Construct using Data Extracts from CBN 2017 Bulletin 
The next important descriptive statistics conducted is a correlation test using the Pearson Correlation test technique. The result is presented in Table 4.2 and the result revealed that there is no perfect relationship existing amongst the variables; the implication of this is that there is no existence of perfect relationship between the dependent variable and the independent variables of each model, meaning that the problem of perfect multicollinearity is avoided.

\subsection{Unit Root Test Result}

To arrive at a robust result and apply the right estimation technique, it is important to verify the stationarity of the time series. It is also important that the variables do not suffer from unit root problem to arrive at consistent results. To test for this, this study employs the Augmented Dickey Fuller (ADF) test. The variables tested are real GDP (RGDP), Industrial Sector contribution to GDP (INDRGDP), Building and Construction Sector contribution to GDP (BUILDRGDP), Trade Sector contribution to GDP (TRADERGDP), Services Sector contribution to GDP (SERVICERGDP), Agricultural Sector contribution to GDP (AGRICRGDP), Government Capital Expenditure (GCE), Credit to Private Sector (CPS), Exchange Rate (NER), Inflation rate (INF), Prime Lending Rate (PLR), Net Export (NE), Rainfall (RF), Index of Electricity Consumption (IEC), Net Export on Services (NES), and Total Government Expenditure (TGE). The results of the stationarity test as presented in Table 4.3 reveal that only inflation rate, net export and growth rate are stationary at levels while others are at first difference; implying that the order of stationarity are mixed. 
Table 4.3. Unit Root Result

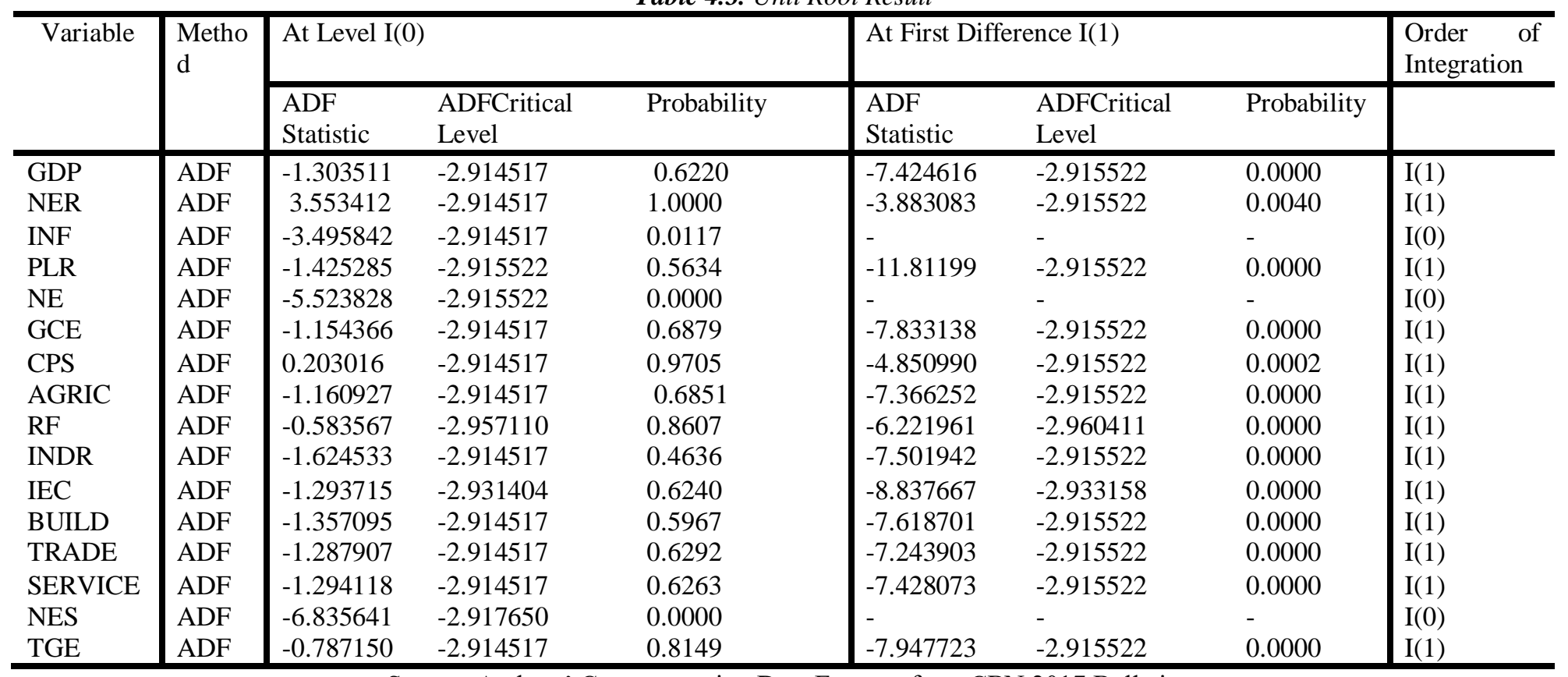

Source: Authors' Construct using Data Extracts from CBN 2017 Bulletin 


\subsection{Co-integration Test}

Given that there exists a mixed order of stationarity, the appropriate cointegration technique to employ is the ARDL Bound test by Peseran (2001). The bound test results are presented in Table 4.4 below.

Table 4.4. Co-integration Result

\begin{tabular}{l|ccc}
\hline \multicolumn{1}{c|}{ Model } & F-stat & I(0) Bound @ 5\% & I(1) Bound @ 5\% \\
\hline Real Output Equation & 3.782516 & 2.45 & 3.61 \\
Agriculture Equation & 2.204349 & 2.45 & 3.61 \\
Industrial Equation & 3.966833 & 2.32 & 3.50 \\
Building Equation & 4.937809 & 2.62 & 3.79 \\
Trade Equation & 5.559144 & 2.45 & 3.61 \\
Service Equation & 4.302731 & 2.45 & 3.61 \\
\hline
\end{tabular}

Source: Authors' Construct using Data Extracts from CBN 2017 Bulletin

Table 4.4 shows the results of cointegration using ARDL bound test by Peseran (2001). The F-statistics values are: Real Output (equation 1) = 3.782516; Agriculture (equation 2) $=2.204349$; Industry (equation 3) $=$ 3.966833; Building (equation 4) $=4.937809$; Trade (equation 5) $=5.559144$ and Service (equation 6) $=4.302731$. From these results, it is clear that all the equations estimated, except Agriculture (equation 2) are cointegrated to the order of one because all their F-statistics value are higher that corresponding upper-bound critical values at 5\% level. This means that the null hypothesis of no cointegration among the variables in equations 1,3,4,5 and 6 is rejected while the null hypothesis of no cointegration among the variables in equation 2 is accepted. The implication of this is that, aside from equation 2 , there exists a cointegration amongst the variable fundamentals.

\subsection{Regression Result}

This section presents the Autoregressive Distributed Lag Model Result of the six equations developed for this study. 
Table 4.5. ARDL Regression Result

\begin{tabular}{|c|c|c|c|c|c|c|c|c|c|c|c|c|}
\hline \multirow[t]{3}{*}{ Variable } & \multicolumn{2}{|c|}{ Real GDP Result } & \multicolumn{2}{|c|}{ Agricultural Equation } & \multicolumn{2}{|c|}{ Industrial Equation } & \multicolumn{2}{|c|}{ Building Equation } & \multicolumn{2}{|c|}{ Trade Equation } & \multicolumn{2}{|c|}{ Services Equation } \\
\hline & \multicolumn{12}{|c|}{ LONG RUN } \\
\hline & Coefficient & t-stat & coefficient & t-stat & coefficient & t-stat & coefficient & t-stat & Coefficient & t-stat & coefficient & t-stat \\
\hline $\begin{array}{c}\text { NER } \\
\text { INF } \\
\text { PLR } \\
\text { NE } \\
\text { LOG(GCE) } \\
\text { LOG(CPS) } \\
\text { RF } \\
\text { IEC } \\
\text { NES } \\
\text { TGE } \\
\text { C }\end{array}$ & $\begin{array}{c}-0.015^{*} \\
0.044^{*} \\
-0.054 \\
0.006 \\
1.451^{*} \\
-0.201 \\
- \\
- \\
- \\
- \\
1.462 \\
\end{array}$ & $\begin{array}{c}-2.58 \\
2.81 \\
-0.27 \\
0.96 \\
4.97 \\
-0.13 \\
- \\
- \\
- \\
- \\
0.16 \\
\end{array}$ & $\begin{array}{c}-0.265^{*} \\
-0.079^{*} \\
0.122 \\
0.000 \\
- \\
2.472^{*} \\
0.006 \\
- \\
- \\
- \\
-29.96^{*}\end{array}$ & $\begin{array}{c}-8.40 \\
-2.31 \\
1.55 \\
-0.22 \\
- \\
9.94 \\
1.21 \\
- \\
- \\
- \\
-4.92 \\
\end{array}$ & $\begin{array}{c}-0.082^{*} \\
-0.104 \\
-0.012 \\
0.003^{*} \\
1.174 \\
1.154 \\
- \\
-0.010 \\
- \\
- \\
-20.20 \\
\end{array}$ & $\begin{array}{c}-2.31 \\
-1.37 \\
-0.07 \\
6.53 \\
0.834 \\
0.73 \\
- \\
-0.20 \\
- \\
- \\
-1.11 \\
\end{array}$ & $\begin{array}{c}-0.016^{*} \\
0.047^{*} \\
-0.088 \\
- \\
1.195^{*} \\
0.086 \\
- \\
- \\
- \\
- \\
-2.800 \\
\end{array}$ & $\begin{array}{c}-3.86 \\
2.37 \\
-0.57 \\
- \\
2.18 \\
0.07 \\
- \\
- \\
- \\
- \\
-0.39\end{array}$ & $\begin{array}{c}-0.030^{*} \\
0.028^{*} \\
-0.028^{*} \\
-0.022 \\
0.842^{*} \\
0.788 \\
- \\
- \\
- \\
- \\
-11.035 \\
\end{array}$ & $\begin{array}{c}-3.16 \\
2.51 \\
-4.14 \\
-1.34 \\
6.58 \\
0.53 \\
- \\
- \\
- \\
- \\
-0.91 \\
\end{array}$ & $\begin{array}{c}-0.050^{*} \\
0.049 \\
-0.075 \\
- \\
- \\
-0.291 \\
- \\
- \\
0.002 \\
1.949 \\
-9.143 \\
\end{array}$ & $\begin{array}{c}-2.32 \\
1.09 \\
-0.44 \\
- \\
- \\
-0.19 \\
- \\
- \\
0.63 \\
1.33 \\
-1.06\end{array}$ \\
\hline $\mathrm{C}$ & \multicolumn{12}{|c|}{ SHORT RUN } \\
\hline $\begin{array}{c}\text { D(NER) } \\
\text { D(NER(-1) } \\
\text { D(NER(-2) } \\
\text { D(INF) } \\
\text { D(PLR) } \\
\text { D(NE) } \\
\text { DLOG(GCE) } \\
\text { DLOG(CPS) } \\
\text { D(RF) } \\
\text { D(IEC) } \\
\text { D(NES) } \\
\text { D(AGRIC(-1) } \\
\text { D(AGRIC(-1) } \\
\text { CointEq(-1) }\end{array}$ & $\begin{array}{c}-0.0025 \\
- \\
- \\
0.0077^{*} \\
-0.0094^{*} \\
-0.0001 \\
-0.7146^{*} \\
-0.0348 \\
-- \\
- \\
- \\
- \\
- \\
-0.1735^{*}\end{array}$ & $\begin{array}{c}-0.52 \\
- \\
- \\
4.89 \\
-5.30 \\
-0.24 \\
-2.01 \\
-0.13 \\
- \\
- \\
- \\
- \\
- \\
-2.98 \\
\end{array}$ & $\begin{array}{c}-0.043^{*} \\
0.131^{*} \\
0.144^{*} \\
0.051^{*} \\
-0.027 \\
-0.001 \\
- \\
-4.105 \\
0.009^{*} \\
- \\
- \\
0.142 \\
0.097 \\
-0.857^{*}\end{array}$ & $\begin{array}{c}-2.47 \\
2.56 \\
2.12 \\
2.50 \\
1.50 \\
-0.97 \\
- \\
-1.78 \\
2.64 \\
- \\
- \\
0.64 \\
0.58 \\
-4.51 \\
\end{array}$ & $\begin{array}{c}-0.021^{*} \\
- \\
- \\
0.031^{*} \\
-0.003 \\
0.0005 \\
-0.970^{*} \\
-1.066 \\
- \\
-0.003 \\
- \\
- \\
- \\
-0.252^{*}\end{array}$ & $\begin{array}{c}-2.20 \\
- \\
- \\
2.11 \\
-0.07 \\
0.58 \\
-2.04 \\
-0.93 \\
- \\
-0.21 \\
- \\
- \\
- \\
-2.13 \\
\end{array}$ & $\begin{array}{c}-0.003 \\
- \\
- \\
0.009 \\
-0.017 \\
- \\
-0.429 \\
0.017 \\
- \\
- \\
- \\
- \\
- \\
-0.193^{*} \\
\end{array}$ & $\begin{array}{c}-0.76 \\
- \\
- \\
1.16 \\
-0.64 \\
- \\
-1.44 \\
0.07 \\
- \\
- \\
- \\
- \\
- \\
-2.28 \\
\end{array}$ & $\begin{array}{c}-0.005^{*} \\
- \\
- \\
0.004 \\
-0.004 \\
-0.0004 \\
-0.154 \\
0.120 \\
- \\
- \\
- \\
- \\
- \\
-0.153^{*}\end{array}$ & $\begin{array}{c}-2.99 \\
- \\
- \\
0.53 \\
-0.14 \\
-0.82 \\
-0.39 \\
0.48 \\
- \\
- \\
- \\
- \\
- \\
-2.71 \\
\end{array}$ & $\begin{array}{c}0.004 \\
- \\
- \\
0.011 \\
-0.017 \\
- \\
1.012 \\
- \\
- \\
- \\
0.0003 \\
- \\
- \\
-0.225^{*} \\
\end{array}$ & $\begin{array}{c}0.41 \\
- \\
- \\
1.16 \\
-0.49 \\
- \\
0.95 \\
- \\
- \\
- \\
0.64 \\
- \\
- \\
-2.37 \\
\end{array}$ \\
\hline CointEq(-1) & \multicolumn{12}{|c|}{ POST-DIAGNOSTIC RESULT } \\
\hline $\begin{array}{c}\mathrm{R}^{2} \\
\text { Adj. } \mathrm{R}^{2} \\
\text { F-stat } \\
\text { D.W. } \\
\text { Ramsey } \\
\text { B.P.G. Prob. } \\
\text { B.G. Prob. } \\
\text { J-B. Prob. }\end{array}$ & $\begin{array}{c}0.97 \\
0.96 \\
139.7 \\
1.89 \\
0.424 \\
0.176 \\
0.457 \\
0.000 \\
\end{array}$ & & $\begin{array}{c}0.99 \\
0.96 \\
29.68 \\
2.30 \\
0.622 \\
0.860 \\
0.053 \\
0.690\end{array}$ & & $\begin{array}{c}0.95 \\
0.93 \\
39.28 \\
2.17 \\
0.454 \\
0.079 \\
0.572 \\
0.000\end{array}$ & & $\begin{array}{c}0.96 \\
0.95 \\
188.8 \\
1.85 \\
0.061 \\
0.174 \\
0.777 \\
0.000\end{array}$ & & $\begin{array}{c}0.97 \\
0.96 \\
98.69 \\
2.00 \\
0.614 \\
0.620 \\
0.819 \\
0.000 \\
\end{array}$ & & $\begin{array}{c}0.97 \\
0.96 \\
107.3 \\
1.72 \\
0.739 \\
0.060 \\
0.294 \\
0.000\end{array}$ & \\
\hline
\end{tabular}


The results of the Autoregressive Distributed Lag Model in Table 4.5 show that in the long run, at the aggregate level of Gross Domestic Product (GDP), the coefficient of nominal exchange rate is negative and statistically significant at 5\%, implying an inverse and significant relationship between exchange rate and aggregate real GDP. An increase in real exchange rate by $1 \%$ leads to a decrease in real GDP by $0.015 \%$. The implication of this is that increase in exchange rate did not spur real output during the period under consideration. This is against economic theory that depreciation of exchange rate increases export and thus strengthens the net export which spurs economic growth. The results also show that for the short run, there was an inverse but insignificant relationship. The results of the five components of the real outputs follow similar pattern with the aggregate real output. It can be seen that the coefficient of exchange rate for the whole five equations in the long run are all negatives. The results reveal the existence of inverse and statistically significant effect of exchange rate on various sectors' outputs in Nigeria. For the agricultural subsector, results in the long run show an increase in real exchange rate by $1 \%$ leads to a decrease in Agriculture GDP by $0.265 \%$. An increase in real exchange rate by $1 \%$ leads to a decrease in Industry GDP by $0.082 \%$, while an increase in real exchange rate by $1 \%$ leads to decrease of 0.016, 0.030 and 0.050 in Building GDP, Trade GDP, and Services GDP respectively.

However, exchange rate has a greater impact on agricultural sector as this impact is up to the magnitude of 0.265 and the least impact on the aggregate economy with the magnitude measures of 0.015 . The reason for this is not farfetched. Given that effective agricultural policies involve the use of machineries and tractors and these are imported. The effect of this is that during exchange rate depreciation, importation becomes highly expensive and, hence, importing capital machineries and equipment becomes constrained by the rising cost of foreign exchange. The effect of exchange rate on Industrial outputs is equally high in magnitude as Agriculture output. A typical explanation can be provided to this behaviour just like the agricultural sector. This may be explained, in part, by the fact that industrial sector in Nigeria also heavily depends on importation of machineries and production plants and even some raw materials. The consequence of rising exchange rate on the sector will be higher cost of machineries and other materials leading to higher cost of production; to this effect, the Industrial sector will be adversely affected by the exchange rate depreciation. Generally, the effect of exchange rate is more pronounced on the outputs of individual subsector than the aggregate real sector of the Nigerian economy. The disparity in the magnitude of effect further affirms the significance of sectoral analysis. The impact of exchange rate on the various sectors in the short run is in conformity with that of the 
long run effect except that only Agriculture, Industry, and Trade sectors have significant relationship with exchange rate.

Inflation has a positive and significant impact on aggregate Real GDP in both short run and long run. This situation is not completely strange as one strand of theoretical argument on the relationship between inflation and output growth posited that inflation could stimulate output (Tobin, 1965; Gregorio, 1996). Also in the short run, results show a negative and significant impact of Prime Lending Rate on Real GD but an insignificant relationship with real GDP in the long run. Also, for the agricultural equation, the results show that there is a negative impact of inflation rate and the intercept on agricultural output while there is a positive impact of prime lending rate, net export, credit to private sector, and rainfall on agricultural output. For the industrial equation, the results show that there is a positive impact of net export, government capital expenditure, and credit to private sector on industrial output while there is an inverse impact of inflation rate, prime lending rate, and index of electricity consumption on industrial output. Further findings from Table 4.5 show that there is a positive impact of inflation rate, government capital expenditure, and credit to private sector on building output, while prime lending rate has negative impact on building output.

Considering the statistical properties of the ARDL results in Table 4.5, the Adjusted R-squared values of between 0.93 and 0.96 indicate that about 93\% to $96 \%$ variation in the real outputs (aggregate and sectors) are explained in the model by the explanatory variables. The F-statistics are statistically significant, implying considerable harmony between real outputs and the explanatory variables put together. This confirms that all the independent variables jointly have a significant effect on the dependent variable. The Durbin-Watson statistic results also indicate that there is no serial correlation associated with the regression results as the highest figure can be approximated as 2 .

Considering the Post Diagnostic test results, the Breusch-PaganGodfrey (BPG) test is a notable test for the presence of heteroscedasticity in a regression result. The BPG probability values for the six equations are greater than 5\% implying there is no presence of heteroscedasticity in the regression results. The Breusch-Godfrey (B-G) Serial Correlation Lagranger Multiplier (LM) test is used to assess for higher order Autoregressive Moving Average (ARMA) errors and is applicable whether or not there is lagged dependent variable(s). The results of the B-G Serial Correlation LM probability in the six equations are all greater than $5 \%$, hence, this study fails to reject the null hypothesis of no serial correlation implying that the model has no higher order ARMA $(p)$ correlation. The Ramsey (Regression Specification Error Test) RESET is used to examine the stability of the ARDL model. The Ramsey RESET tests for specification error in terms of omitted variables, incorrect 
functional form, and correlation between the explanatory variables and the error term. The results reveal that the model is free from specification error. The Jarque-Bera statistics test for the normality distribution of the equation, against the alternative hypothesis. The Jarque-Bera test reveals that the equations are not normally distributed as the probability values are less than $5 \%$. In the model, the error correction term CointEq $\mathrm{t}_{\mathrm{t}-1}$ is well specified and correctly signed. The negative sign in the CointEq $\mathrm{t}_{\mathrm{t}-1}$ confirmed the existence of co-integrating relationship. Also, the error correction term shows that for all the six equations, any short run disequilibrium corrects itself in the long run.

The results of this study have implications on both the operators of the different sectors of the Nigerian real economy, monetary authorities (CBN), and the policy makers. A sound exchange rate policy is very critical and significant to achieving increased performance of the Nigerian real sector. Further, the direction of impact of Exchange rate on the real output was similar for the aggregate economy and the disaggregated sectors of the real economy. The exchange rate had an inverse (negative) and significant effect on both the aggregate output and the outputs of the five real sectors; agriculture, industry, building and construction, trade, and services. However, this finding calls for caution as the homogenous behaviour of the aggregate and disaggregated real output in terms of response to exchange rate does not rule out structural differences in sectors and the need for regulators and policy makers to approach the economy as the disaggregated component rather than looking at aggregate dimension. The peculiarities of different sectors have implications for growth especially in a typical developing nation like Nigeria.

\section{Conclusion}

This study investigates the relationship between exchange rate fluctuation and the performance of real sector in Nigeria; looking at disaggregated components of agricultural, industrial, building and construction, wholesale and retail trade, and services with the scope spanning thirty-two years (1986- 2017). The study adopts the modified MundellFleming IS-LM framework using Autoregressive Distributed Lag (ARDL) technique and establishes an inverse (negative) and significant relationship between exchange rate and real output; at both aggregate and sectoral levels within the period under consideration. The implication is that exchange rate hampered rather than spurred the performance of the Nigerian real sector and subsectors during the period under examination. This homogenous response of the output of the sectors to exchange rate is in contrast with studies of Yaqub (2010), Amoo et al. (2014), and Olajide (2016) which established that the sectors of the economy responded heterogeneously to exchange rate change. However, the pattern of each sector's response to exchange rate change is far 
from pure homogeneity, affirming the disparity in terms of size, magnitude, and capital intensity of each of the sectors and justification for sectoral analysis. It also reinforces the need for policy makers to adopt sector specific exchange rate policies to drive each of the component sectors of the Nigerian real sector to achieve overall development in the real sector of the Nigeria economy.

Large scale agricultural activities should be encouraged by government through incentives and subsidies to local farmers so as to increase the sector's contribution to gross domestic product and employment within the country. This will also help to increase local sourcing of raw materials and input for the industries through agriculture, consequently reducing pressure on exchange rate that usually arise from sourcing for such raw materials and inputs from abroad. This will also help to strengthen the link between agriculture and the industrial sectors, leading to total revamp of the entire real economy. Again, in view of the established nexus between real output and these other macroeconomic variables like inflation rate, government expenditures, credit to private sector among others on output, the monetary authority $(\mathrm{CBN})$ should formulate an exchange rate policy that align with government domestic monetary policy and fiscal policy. More so, there should be a credible coordination and harmony between fiscal and monetary policies to achieve macroeconomic stability.

\section{References:}

1. Adeniyi, J.A. (2012). Employment effect of exchange rate volatility in Nigeria's manufacturing sector. Journal of Economic Theory, 6(1), 1425.

2. Adeusi, S.O. \& Aluko, O.A. (2015). Relevance of financial sector development on real sector productivity: 21st century evidence from Nigerian industrial sector. International Journal of Academic Research in Business and Social Sciences, 5(6), 118-132.

3. Akinlo O.O. \& Lawal, Q.A. (2015). Impact of exchange rate on industrial production in Nigeria (1986-2010), International Business and Management, 10 (1), 104-110.

4. Akpan, E.O. \& Atan, A.A. (2012). Effects of exchange rate movements on economic growth in Nigeria. CBN Journal of Applied Statistics, 2(2), 1-14.

5. Aliyu, S.R.U. (2008). Exchange rate volatility and export trade in Nigeria: An empirical investigation. Munich Pers. RePEc Arch (MPRA) Paper 13490.

6. Amoo, B.A.G., Odey, L.I., Kanya, W., Eboreime, M., Ekeocha, P., Akpan, N.I., ... Ochu, E.R. (2014). Effects of monetary policy on the 
real economy of Nigeria: A Disaggregated Analysis. CBN Occasional Paper 54, 1-65.

7. Anyanwu, C.M. (2010). An overview of current banking sector reforms and the real sector of the Nigerian Economy", Central Bank of Nigeria (CBN) Economic and Financial Review 48(4), 31-57.

8. Ayodele, A.I. (2004). Real Sector policies in the 2004 Budget. CBN Bullion, 28 (2), 41-48.

9. Bernanke, B.S. \& Gertler, M. (1995). Inside the black box: The credit channel of the monetary policy transmission, Journal of Economic Perspectives, 9 (4), 27-48.

10. Campbell, O.A. (2010). Foreign exchange market and monetary management in Nigeria, Journal of Emerging Trends in Economics and Management Sciences (JETEMS), 1(2), 102-106.

11. Chang, 1. 1. \& Tan, H. B. (2008). Exchange rate risk and macroeconomics fundamental, evidence from our neighbouring South East Asian economies. International Research Journal of Finance and Economics, 16, 88-99.

12. Diaz-Alejandro, F. C. (1965). Exchange-Rate depreciation in a SemiIndustrialized Country: The

13. experience of Argentina, 1955-61. Cambridge, Mass.: MIT Press.

14. Dickey. D. \& Fuller, W.A. (1981). Likelihood Ratio Statistics for Autoregressive Time Series with a Unit Root, Econometrica, 49 (4), 1057-1072

15. Fapetu, O. \& Oloyede, J.A. (2014). Foreign exchange management and the Nigerian economic growth (1960 - 2012), European Journal of Business and Innovation Research ,2(2), 19 -31.

16. Fleming, J. M. (1962). Domestic financial policies under fixed and floating exchange rates. IMF Staff Papers 9, 369-37. Reprinted in Cooper, Richard N., ed. (1969). International Finance. New York: Penguin Books.

17. Gregorio, J. (1996). Inflation, growth and Central Banks: Theory and Evidence, Ministry of Finance Paper, Santiago Chile.

18. Ibadin, L.A, Moni, O.M, \& Eikhomun, D.E. (2014). Real sector, gross fixed capital formation and the Nigerian Stock market. European Journal of Business and Management, 6(33), 157-168.

19. International Monetary Fund. (2016). World Economic Outlook: Subdued Demand: Symptoms and Remedies. Washington DC, October. 
20. International Monetary Fund. (2017). Regional Economic Outlook: Sub-Saharan Africa Restarting the Growth Engine. Washington DC, April.

21. Jhingan, M.L. (2003). Money, Banking, International Trade and Public Finance. New A.S. Offset Press, Delhi.

22. Johansen, S. (1988). Statistical analysis of cointegrating vectors, Journal of Economic Dynamic and Control, 12(June-Sept), 231-54.

23. Kamin, S. B. \& Klau, M. (1998). Some multi-country evidence on the effects of real exchange rates on output. International Finance Discussion Papers, 611. Washington, D.C.: Federal Reserve Board.

24. Kandil, M. (2004). Exchange rate fluctuation and economic activities in developing countries: Theory and evidence. Journal of Economic Development,29 (1), 85-155.

25. Kandil, M., \& Mirzaie, I. A. (2002). Exchange Rate Fluctuations and Disaggregated Economic Activity in the US: Theory and Evidence, Journal of International Money and Finance, 21, 1-31.

26. Kandil, M. \& Mirzaie, I.A. (2005). "The Effects of Exchange Rate Fluctuations on Output and prices:

27. Evidence from Developing Countries," Journal of Developing Areas, 38, 189-219.

28. Kowalski, P., Paczynski, W. \& Rawdanowicz, L. (2003), Exchange rate regime and real sector: A sectoral analysis of CEE Countries, PostCommunist Economies, 15 (4), 533-555.

29. Levy-Yeyati, E. \& Sturzenegger, F. (2003). To float or to fix: Evidence on the impact of exchange rate regimes on growth, The American Economic Review, 93(4), 1173-1193.

30. Llaudes, R. (2007). Monetary policy shocks in a two-sector open economy: An Empirical Study, ECB working paper No 441.

31. Mordi, M.C. (2006). Challenges of exchange rate volatility in economic management in Nigeria. CBN Bullion ,30 (3), 17-25.

32. Mordi C.N., Adebiyi, M.A., Adenuga, A.O., Adebayo, O.M., Abeng, M.O., Akpan, I.N. ... Evbuomwan, O.O. (2013). Modeling the real sector of the Nigerian economy. CBN, Research Department, 1-59.

33. Moreno, R. (2001). Pegging and stabilization policy in developing Countries. Economic Review of the Federal Reserve Bank of San Francisco, 12(99), 17-29.

34. Mundell, R.A. (1963). "Capital mobility and stabilization policy under fixed and flexible exchange rates". Canadian Journal of Economic and 
Political Science 29 (4),475-485. Reprinted in Mundell, Robert A. (1968). International Economics. New York: Macmillan.

35. Musa, Y. \& Sanusi, J.A. (2013). Industrial output response to inflation and exchange rate in Nigeria: An mmpirical Analysis, Journal of Economics and Sustainable Development, 4 (20), 74-81.

36. Narayan, P.K. (2004). Reformulating critical values for the bounds Fstatistics approach to cointegration: an application to the tourism demand model for Fiji. Discussion paper No. 02/04, Department of Economics, Monash University Australia.

37. National Bureau of Statistics (2014). Measuring Better: Presentation of Preliminary Results of The Rebased Nominal Gross Domestic Product (GDP) Estimates for Nigeria 2010 to 2013 delivered by The Statistician-General of the Federation \& Chief Executive Officer, NBS, Dr. Yemi Kale, Abuja. 6 April 2014.

38. Ngerebo-a., T.A \& Ibe., R. C (2013). Exchange rate and macroeconomic performance in Nigeria: A Causal Post Structural Adjustment Programme Investigation. Global Journal of Management and BusinessResearch Finance, 13(7).

39. Obadan, M.I. (2006). Overview of exchange rate management in Nigeria from 1986 to Date. CBN Bullion, 30(3), 1-9.

40. Obayelu, A.E. \&Salau, A.S. (2010). Agricultural response of prices and exchange rate in Nigeria: Application of cointegration and vector error correction model (VECM). Journal of Agricultural Science.1(2):73-81.

41. Odusola, A. (2006). Economics of exchange rate management. CBN Bullion 30(2), 38-44.

42. Oladipupo, A. O \& Ogheneov, O. F. (2011). Impact of Exchange Rate on Balance of Paymentin Nigeria. African Research Reviews. 5 (4): 73-88.

43. Olajide, V.C. (2016). Real Sector Performance and Exchange Rate Dynamics in Nigeria.

44. Olorunfemi, S. \& Fatukasi, A.A. (2011). An Appraisal of foreign exchange resources generation and management, Journal of Social Sciences 7 (4), 579-585.

45. Oloyede, J. A. (2002). Principles of International Finance, Forthright Educational Publishers, Lagos.

46. Oyejide, T.A. (1985). Exchange rate policy for Nigeria: Some options and their consequences. Proceedings of the one day Workshop of Economic Society of Nigeria, July 4, 1985. 
47. Peseran, M.H., \& Perasan, B. (1997). Working with Microfit 4.0: Interactive Econometrics Analysis. Oxford University Press.

48. Pesaran, M. H. \& Smith, R. J. (1998). Structural analysis of cointegration VARS. Journal of Economic Surveys. 12, 471-505.

49. Pesaran, M.H., Shin, Y. \& Smith, R.J. (2001). Bounds testing approach to the analysis of level relationship, Journal of Applied Econometrics, 6: 289-326.

50. Philips, P.C. \& Perron, P. (1988). Testing for a Unit Root in Time Series Regression, Biometrika, 75 (2), 335-346.

51. Raddatz, C. \& R. Rigobon (2003). Monetary policy and sectoral shocks: Did the Fed React properly to the high tech crisis? Policy Research Working Paper 3160, The World Bank.

52. Sanusi, L.S. (2011). Growing Nigeria's real sector for employment and economic development: The role of Central Bank of Nigeria. Being a paper delivered at the inaugural memorial lecture in honour of late Professor OkefieUzoaga at the University of Nigeria, Nsukka, Enugu State on July 2, 2011.

53. Tobin, J. (1965). Money and Economic Growth, Econometrica, 33, 671-684.

54. World Bank (2017). Nigeria economic outlook. Washington DC, April.

55. Yaqub, J.O. (2010). Exchange rate changes and output performance in Nigeria: A sectorial analysis, Pakistan Journal of Social Sciences, 7 (5), 380-387. 